\title{
The Effect of Picloram and Thidiazuron Concentrations on Prolif- eration Somatic Embryos from Immature Inflorescence of Date palm Rehab A. Sidky
}

The Central laboratory of Date palm Researches and Development, Agric. Research Center, Egypt.

sidky1234rehab@hotmail.com

\begin{abstract}
:
Immature inflorescences of date palm (Phoenix dactylifer) cv. Sewi were used as explants for in vitro culture to investigate the effect of plant growth regulators on inflorescence proliferation. The inflorescences on initiation stage cultured on solidified Murashige and Skoog (MS) basal medium supplemented with Picloram 1, 5, 10 and $15 \mathrm{mg}^{-1}$ for two re-cultures. Then, transferred into medium supplemented with different concentrations of TDZ combined with NAA on proliferate stage. The optimal concentrations for successful inflorescence growth was 5 or $10 \mathrm{mg} \mathrm{l}^{-1}$ Picloram and through studying the residuals effect of Picloram on inflorescences proliferation in the presence of three concentrations of TDZ, it found that, $0.5 \mathrm{mg}^{-1} \mathrm{TDZ}$ combined with $0.1 \mathrm{mg} \mathrm{l}^{-1} \mathrm{NAA}$ was more effective to induce direct somatic embryos and gave the highest inflorescence proliferation percentage, while the high level of Picloram induced callus. Vegetative shoots formed into media containing $0.1 \mathrm{NAA} \mathrm{mg}^{-1}, 0.2 \mathrm{mg} \mathrm{l}^{-1} \mathrm{BA}$ and 0.2 $\mathrm{mg}^{-1}$ kin. All somatic embryos were converted successfully to healthy normal plantlets which could be transferred to greenhouse.
\end{abstract}

Keywords: Phoenix dactylifera, in vitro inflorescences, direct somatic embryos, Picloram, TDZ

Abbreviation: Picloram (4-amino-3,5,6-trichloropicolinic acid), Thidiazuron $(N$ phenyl- $N^{\prime}$-1,2,3-thiadiazol-5-ylurea), NAA (naphthaleneacetic acid), BA (6-Benzylaminopurine), kin (kinetin).

Received on: 1/1/2014

Referees: Prof. Farouk M. A. Mostafa
Accepted for publication on: 19/1/2014

Prof. Abd ElFattah M. ElSalehi 


\section{Introduction:}

Date palm, Phoenix dactylifera L., is one of the oldest fruit trees in the world and is mentioned in the Holy Qur'an and Bible. Date palm is one of the most important fruit trees in the Middle East and in the Saharan and Sub-Saharan regions of Africa. In some areas, this is the only tree which provides food, shelter and fuel to the communities. Dates are not only a staple food but are also an important export cash crop (Zaid and Hegarty 2006). Conventional propagation is by offshoots making it slow to establish new date palm plantations. Moreover, several genotypes do not produce offshoots while others are difficult to root. In addition seedpropagated palms do not bear true to type due to heterozygosis and require up to 7 years reaching fruiting stage. The need for rapid and efficient vegetative propagation systems for elite genotypes has therefore become urgent. Since 1970 intensive efforts have been undertaken into large-scale micropropagation of date palm using techniques such as somatic embryogenesis and organogenesis (Drira 1983; Drira and Benbadis 1985; Tisserat 1979; ElHadrami et al. 1998).

Exogenously supplied plant growth regulators are essential for somatic embryogenesis (Ammirato 1983). Most tissue culture studies of palms have focused on the effects of different auxin types and concentrations on various explants cultures as investigated in date palm (Othmani et al. 2009, Eke et al. 2005), macaw palm (Moura et al. 2009), and coconut (Verdeil et al., 1989 and Verdeil et al.,1994). Picloram has recently been reported to be successful in Arecanut palm tissue culture in terms of callus and somatic embryo produc- tion. The continuous production of embryonic calli from the initial explants indicates the potential of the protocol for multiplication of palms (Karun et al. 2004).

Thidiazuron has been used successfully in vitro to induce adventitious shoot formation and to promote axillary shoot proliferation (Chin-Yi Lu, 1993). The ability of TDZ to stimulate cell division has been demonstrated in soybean callus.Apart from stimulating cell division, TDZ had also been shown to induce adventitious shoot formation from tobacco leaf discs and to stimulate radish cotyledon expansion (Thomas and Katterman, 1986).

The objective of this study was to investigate inflorescence proliferation of Phoenix dactylifera cv. sewi maintained in the immature phase and induced somatic embryos directly. We also systematically examined the residual effects of picloram and the change composition of media to another type of growth regulators like thidiazuron (TDZ) and naphthalene acetic acid (NAA) on proliferation percentage.

\section{Materials and Methods: Plant material:}

Two distinct steps were followed:

The first step had been done outside the laminar flow hood and before cutting the spathes, they were sprayed with $70 \%$ ethanol and burned for a few seconds to burn the external hairs. The second step took place under aseptic condition into laminar air flow hood. The spathes were gently opened with sterilized scalpel then the spikelets were soaked in mercuric chloride $\left(\mathrm{Hg} \mathrm{Cl}_{2}\right)$ at $0.1 \%$ for $15 \mathrm{~min}$. The explants of inflorescences were rinsed three times with sterilized distilled water. 
Spikelet of length $(7-10 \mathrm{~cm})$ were cut into $1-3 \mathrm{~cm}$ long pieces which each piece carries many florets (Fig.1a,b) Sidky and Eldawyati, 2012)

\section{Inflorescence Initiation (first stage)}

To establish direct somatic of Phoenix dactylifera cv. Sewi, we first cultured of Spikelets explants of length $(7-10 \mathrm{~cm})$ on half macro and full micro elements of Murashig and Skoog (1962) combined with $40 \mathrm{mg}^{-1}$ adenine-Sulphate,

$5 \mathrm{mg}^{-1}$ thiamin- $\mathrm{HCl}, 100 \mathrm{mg}^{-1}$ myoinositol, $200 \mathrm{mg}^{-1}$ glutamine, 0.5 $\mathrm{g}^{-1}$ activated charcoal, $50 \mathrm{~g}^{-1}$ sucrose and $5.0 \mathrm{~g}^{-1}$ agar with different concentration of Picloram 1,5,10, and $15 \mathrm{mg} \mathrm{l}^{-1}$. Effects of treatments were evaluated after two re-cultures (12 weeks). Data collection and reculturing were performed at 6 weeks intervals. $\mathrm{pH}$ of each medium was adjusted to $5.7 \pm 0.1$ prior to addition of agar, the medium were distributed into culture small jars $(150 \mathrm{ml})$, the jars were autoclaved at $121^{\circ} \mathrm{C}$ and 1.2 $\mathrm{kg} / \mathrm{cm}^{2}$ for $20 \mathrm{~min}$. Culture of all treatments was incubated under complete darkness at $27 \pm 2 \mathrm{C}^{\circ}$. Data were taken on swelling and browning rate.

Inflorescence proliferation (second stage):

In order to examine the effects of plant growth regulators on inflorescence proliferation, we added TDZ at $0.1,0.5$ and $1.0 \mathrm{mg} \mathrm{l}^{-1}$ combined with $0.1 \mathrm{mg} \mathrm{l}^{-1}$ NAA to half MS basal medium the explants re-cultured every 6 weeks for twice. As soon as somatic embryos were germinated, it was transferred into MS solid medium containing $0.1 \mathrm{NAA} \mathrm{mg/1}+0.2$ $\mathrm{mg} / 1 \mathrm{BA}+0.2 \mathrm{mg} / 1 \mathrm{kin}, 200 \mathrm{mg} \mathrm{l}^{-1}$ $\mathrm{KH}_{2} \mathrm{PO}_{4}, 40 \mathrm{~g} \mathrm{l}^{-1}$ sucrose and $0.3 \mathrm{~g} \mathrm{l}^{-1}$ AC (Sidky and Gadalla 2013). Plantlets were transferred to rooting me- dia. Data were calculated after each culture as follows:

1- Number of direct somatic embryos.

2- Percentage of direct somatic embryos.

3- Callus initiation degree/explant.

(This data Scored visually according to Pottino (1981) as follow:

Negative results (-) 1

Average results $(+) 2$

Good results $(+++) 3$

\section{Rooting stage}

Plantlets were cultured on $1 / 2$ MS liquid medium supplemented with $1.0 \mathrm{NAA} \mathrm{mg} \mathrm{l}^{-1}, 200 \mathrm{mg} \mathrm{l}^{-1}$ $\mathrm{mg} / 1 \mathrm{KH}_{2} \mathrm{PO}_{4}, 40 \mathrm{~g} \mathrm{l}^{-1}$ sucrose, 100 $\mathrm{mg}^{-1}$ myoinsitol and $1 \mathrm{~g}^{-1} \mathrm{AC}$, and incubated under 6000 lux light( Fig.1g), then rooting and eventually successfully transplanted in the greenhouse.

\section{Statistical Analysis:}

The randomized factorial design was used and data were subjected to analysis of variance. Separation of means among treatments was determined using L.S.D test at 5\% according to Snedecor and Cochran (1980).

\section{Result and Discussions:}

\section{Effects of picloram on Inflores- cence Initiation:}

The immature flower buds were swelling after 6 weeks, some culture turned brown, but several of them enlarged and gave different response (Table 1 and Fig 1c). This culture had to be re-cultured after another 6 weeks to promote further growth. The highest swelling rate $(73.33 \%)$ was obtained at $5 \mathrm{mg} \mathrm{l}^{-1}$ picloram concentrations. However; this is not statistically significant at $15 \mathrm{mg} \mathrm{l}^{-1}$ picloram (33.33\%). Zimmerman, (1993) reported that the pro embryogenic callus were containing auxins to synthe- 
size all the necessary genes to complete the globular stage. However, the auxins were removed from the culture to make inactive genes or synthesize new gene products for the completion of embryo development. Kawahara and Komamine (1995) reported that, the exogenous auxins were involved in gene expression of early stages of somatic embryogenesis.

Similarly, browning rate differed according to picloram concen- trations and ranged from $20.00 \%$ to $46.66 \%$, the lowest browning rate was obtained at $5 \mathrm{mg} . \mathrm{l}^{-1}$ picloram concentration. While, $46.66 \%$ of these culture turned brown at $1 \mathrm{mg} 1^{-}$ ${ }^{1}$ picloram. 2, 4-D at levels higher than $30 \times 10 \mathrm{M}$ inhibited callusing and enhanced browning of coconut embryos (Karunaratne and Periyapperuma 1989).

Table (1): Effect of different Picloram concentrations on the Swelling and Browning rate (\%) on the first stage.

\begin{tabular}{|c|c|c|}
\hline Picloram $\left(\mathbf{m g ~ l}^{-1}\right)$ & Swelling\% & Browning\% \\
\hline 1 & 53.33 & 46.66 \\
\hline 5 & 73.33 & 20.00 \\
\hline 10 & 46.66 & 40.00 \\
\hline 15 & 33.33 & 26.66 \\
\hline Mean & $\mathbf{5 1 . 6 6}$ & $\mathbf{3 3 . 3 3}$ \\
\hline
\end{tabular}

L.S.D. at 0.05

23.07

17.62

Effects of TDZ on inflorescence proliferation:

Three concentrations of TDZ were tested combined with $0.1 \mathrm{mg} \mathrm{l}^{-1}$
NAA for their effect on date palm inflorescence proliferation (Table 2 and Fig. 1e,f).

Table (2): Effect of auxin residues on number of direct somatic embryos after transferring to cytokinin concentration.

\begin{tabular}{|c|c|c|c|c|c|}
\hline \multirow{2}{*}{$\begin{array}{c}\text { TDZconcentration+ } \\
0.1 \mathrm{mg} \mathrm{l}^{-1} \mathrm{NAA} \\
\text { (A) }\end{array}$} & \multicolumn{5}{|c|}{ Previous Treatment Picloram (B) } \\
\hline & $1 \mathrm{mg} \mathrm{l}^{-1}$ & $5 \mathrm{mg} \mathrm{l}^{-1}$ & $10 \mathrm{mg} \mathrm{l}^{-1}$ & $15 \mathrm{mg} \mathrm{l}^{-1}$ & Mean \\
\hline $0.1 \mathrm{mg} \mathrm{l}^{-1}$ & 1.00 & 1.00 & 3.66 & 3.00 & 2.16 \\
\hline $0.5 \mathrm{mg} \mathrm{l}^{-1}$ & 2.00 & 7.00 & 5.33 & 3.33 & 4.41 \\
\hline $1.0 \mathrm{mg} \mathrm{I}^{-1}$ & 1.00 & 5.33 & 4.00 & 3.00 & 3.33 \\
\hline Mean & 1.33 & 4.44 & 4.33 & 3.11 & \\
\hline
\end{tabular}

Twelve weeks after culture initiation on media containing auxin (Fig. 1d), inflorescence buds transferring into media containing cytokinin, Zimmerman, (1993) reported that the pro embryogenic callus were containing auxins to synthesize all the neces- sary genes to complete the globular stage. After six weeks we observed growth of structures like globular, the structures proliferation to direct somatic embryos after another six weeks (Fig. 1e,f) . Residual effect of picloram observed in (Table 2). $5 \mathrm{mg}$ 
$1^{-1}$ or $10 \mathrm{mg}^{-1}$ picloram produced the highest direct embryos (4.44, 4.33 embryos /culture). The addition of a cytokinin resulted essential to promote growth of somatic embryos from immature flowers, direct somatic embryos occurred at all TDZ concentrations tested, the highest direct of somatic embryos was obtained after floral buds were cultured on medium containing $0.5 \mathrm{mg} \mathrm{l}^{-1} \mathrm{TDZ}$ $+0.1 \mathrm{mgl}^{-1}$ NAA $\quad(4.41$ embryos /culture).

There was also a significant interaction between TDZ concentrations and picloram concentrations. The interaction between $5 \mathrm{mg} \mathrm{l}^{-1}$ pi- cloram and $0.5 \mathrm{mg}^{-1} \mathrm{TDZ}+0.1 \mathrm{mgl}^{-1}$ NAA gave the significant result of direct embryos (7 embryos /culture). These results suggested that changing the medium composition could significantly change the number of direct somatic embryos .This type of response shows similarities with the flower bud-like structures observed by Verron et al. (1995) in the monocot lily of the valley, also in bamboo and ginseng explants, which have been shown to flower and thereof proliferate inflorescences in vitro in medium containing TDZ (Lin et al. 2003; 2004).
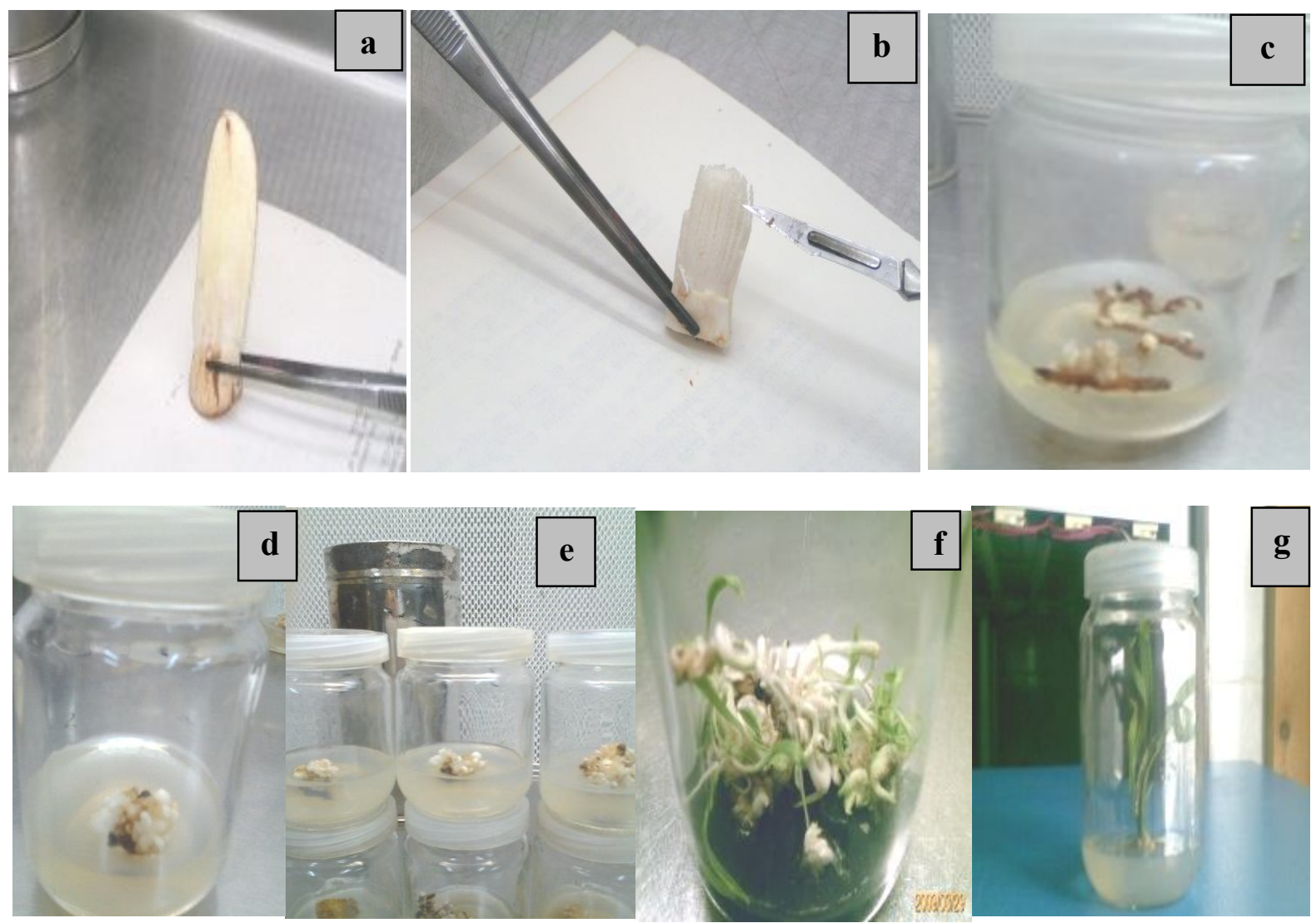

Fig. 1 a) The spathe from $7-10 \mathrm{~cm}$, b) Explant after remove the outer protective sheath, c) Swilling of explant, d) Initiation of Explant, e) Flower bud-like structures, f) Explant proliferation to embryos, g) Healthy plantlets 
Table (3): Effect of auxin residues on proliferation embryos percentage after transferring to cytokinin concentration.

\begin{tabular}{|c|c|c|c|c|c|}
\hline \multirow{2}{*}{$\begin{array}{l}\text { TDZconcentration+ } \\
0.1 \mathrm{mg} \mathrm{l}^{-1} \text { NAA } \\
\text { (A) }\end{array}$} & \multicolumn{5}{|c|}{ Previous Treatment Picloram (B) } \\
\hline & $1 \mathrm{mg} \mathrm{l}^{-1}$ & $5 \mathrm{mg} \mathrm{l}^{-1}$ & $10 \mathrm{mg} \mathrm{l}^{-1}$ & $15 \mathrm{mg} \mathrm{l}^{-1}$ & Mean \\
\hline $0.1 \mathrm{mg} \mathrm{l}^{-1}$ & 30.00 & 56.67 & 76.67 & 63.33 & 56.66 \\
\hline $0.5 \mathrm{mg} \mathrm{l}^{-1}$ & 73.33 & 93.33 & 93.33 & 83.33 & 85.83 \\
\hline $1.0 \mathrm{mg} \mathrm{l}^{-1}$ & 40.00 & 83.33 & 83.33 & 53.33 & 64.99 \\
\hline Mean & 47.77 & 77.77 & 84.44 & 66.66 & \\
\hline
\end{tabular}

$\begin{array}{llll}\text { L.S.D. at } 0.05 & (\mathrm{~A})=6.63 & (\mathrm{~B})=7.65 & \mathrm{AB}=13.26\end{array}$

The effects of residual concentrations of picloram on the percentage of proliferation embryos are investigated in (Table 3, Fig.1f). Medium containing $10 \mathrm{mg} \mathrm{l}^{-1}$ picloram gave the maximum proliferation embryos response $(84.44 \%)$. On the other hand, the highest proliferation embryos were obtained after floral buds were cultured on medium containing $0.5 \mathrm{mg} \mathrm{l}^{-1} \mathrm{TDZ}$ (85.83\%).

We also showed that the effect of picloram concentrations interaction with TDZ concentrations on proliferation embryos percentage. The highest percentage of proliferation embryos were occurred on medium ranged from $1 \mathrm{mg} \mathrm{l}^{-1}$ to $15 \mathrm{mg} \mathrm{l}^{-1}$ picloram concentrations with medium containing $0.5 \mathrm{mg}^{-1} \mathrm{TDZ}$.

The result of the study showed that proliferation embryos percent- age, from the immature inflorescence was significantly affected by the changing the medium composition. Picloram concentration residues significantly with another type of growth regulator enhanced embryos proliferation. Lin et al.2006,, conclude that TDZ is essential for inflorescence proliferation. Somatic embryo like structures have been observed on walnut immature cotyledons cultured on woody plant medium containing TDZ $(0.11$ or $1.1 \mathrm{mg} /$ liter $)$ and $2,4-$ dichlorophenoxyacetic acid (2,4-D) Neuman et al.1988. More recently, somatic embryogenesis was reported in watermelon (Compton and Gray, 1992) and muskmelon (Gray et al, 1992), again on medium with TDZ and 2,4-D.

Table (4): Effect of auxin residues on callus initiation after transferring to cytokinin treatments

\begin{tabular}{|c|c|c|c|c|c|}
\hline \multirow{2}{*}{$\begin{array}{c}\text { TDZconcentration+ } \\
0.1 \mathrm{mg} \mathrm{I}^{-1} \text { NAA } \\
\text { (A) }\end{array}$} & \multicolumn{5}{|c|}{ Previous Treatment Picloram (B) } \\
\hline & $1 \mathrm{mg} \mathrm{l}^{-1}$ & $5 \mathrm{mg} \mathrm{l}^{-1}$ & $10 \mathrm{mg} \mathrm{l}^{-1}$ & $15 \mathrm{mg} \mathrm{l}^{-1}$ & Mean \\
\hline $0.1 \mathrm{mg} \mathrm{l}^{-1}$ & 1.00 & 2.00 & 1.00 & 2.33 & 1.58 \\
\hline $0.5 \mathrm{mg} \mathrm{l}^{-1}$ & 1.33 & 1.33 & 1.66 & 1.66 & 1.49 \\
\hline $1.0 \mathrm{mg} \mathrm{l}^{-1}$ & 1.66 & 1.33 & 2.00 & 1.66 & 1.66 \\
\hline Mean & 1.33 & 1.55 & 1.55 & 1.88 & \\
\hline
\end{tabular}

$\begin{array}{llll}\text { L.S.D. at } 0.05 & (\mathrm{~A})=0.58 & (\mathrm{~B})=0.68 & \mathrm{AB}=1.17\end{array}$


The results showed that effects of picloram concentrations on the callus induction from explants were significantly different in Table 4 . We observed some flower buds produced callus, the highest callus induction obtained in the high level of picloram at $15 \mathrm{mg} \mathrm{l}^{-1}$ (1.88 degree/jar) On the other hand, transferring the initial explants to medium containing TDZ at $1.0 \mathrm{mg}^{-1}$ often increasing callus (1.66 degree/jar) We also showed that the effect of picloram concentrations interaction with TDZ concentrations on callus degree, the highest callus degree were occurred on medium containing $10 \mathrm{mg} \mathrm{l}^{-1}$ with medium containing $1.0 \mathrm{mg} \mathrm{l}^{-1}$ TDZ( 2.00 degree/jar). Ahmed et al. 2011 reported that, the callus initiation didn't occur without the growth regulators. Induction of somatic embryos on medium containing picloram has also been reported in many species (Castillo et al. 1998; Mendoza and Kaeppler, 2002; Preeti and Kothari, 2004).

\section{Acknowledgements:}

I am grateful to Professor Ezz Gadalla for his help of Statistical analysis and his collaboration.

\section{Reference:}

Ahmed, A. B. A.; Rao, A.S; Rao, M.V. and R.M., Taha. 2011. Effect ofPicloram, Additives and Plant Growth Regulators on Somatic Embryogenesis of Phyla nodiflora (L.) Greene. Brazilian Archives of Biology and Technology, 54: 7-13.

Ammirato, P.V. 1983. Technique in Propagation and Breeding. Handbook of Plant Cell Culture, vol. 1. Mac Millan, NewYork, pp. 82-123.

Castillo, A.M, Egana, B.; Sanz, J. and L.,Cistue. 1998. Somatic embryogenesis and plant regenera- tion from barley cultivars grown in Spain. Plant Cell Report 17: 902-906.

Chin-Yi L.u. 1993. The use of thidiazuron in tissue culture. In Vitro Cellular \& Developmental Biology - Plant.29:29-96.

Compton, M. E. and D. J., Gray. 1992. Somatic embryogenesis on immature cotyledons of watermelon. In Vitro Cell. Dev. Biol. 28:98A.

Drira, N. 1983. Multiplication ve'ge'tative du palmier dattier (Phoenix dactylifera L.) par la culture in vitro de bourgeons axillaires et de feuilles qui en de'rivent. C R Acad Sci Paris, 296:1077-1082.

Drira, N. and A., Benbadis. 1985. Multiplication ve'ge'tative du palmier dattier (Phoenix dactylifera L.) par reversion, en culture in vitro, d'e'bauches florales de pieds females adultes. $\mathbf{J}$ Plant Physiol, 119:227-235.

Eke, C. R.; Akomeah, P. and O. Asemota. 2005. Somatic embryogenesis in date palm (Phoenix dactylifera L.) from apical meristem tissues from 'zebia' and loko'landraces. African Journal of Biotechnology, 4: 244-246.

El Hadram, I;El Bellaj, M.; El Idrissi, A.; J'Aiti, F., El Jaafari, S. and F. Daayf. 1998. Biotechnologies ve'ge'tales et ame'lioration du Palmier dattier (phoenix dactylifer $a$ L.) Pivot de l'agriculture oasienne Marocaine. Cah Agric, 7:463-468.

Gray, D. J.; McColley; D. W. and M. E., Compton. 1992. Effects of cytokinins, genotype and other factors on somatic embryogenesis from cotyledons of Cucumis 
melo. In Vitro Cell. Dev. Biol. 28:101A.

Karun, A.; Siril, E. A.; Radha, E. and V. A., Parthasarathy. 2004. Somatic embryogenesis and plantlet regeneration from leaf and inflorescence explants of arecanut (Area catechu L.). Current Science, 86: 1623-1628.

Karunaratne S. and K., Periyapperuma. 1989. Culture of immature embryos of coconut, L.: callus proliferation and somatic embryogenesis. Plant Science 62:247-53.

Kawahara, R. and A., Komamine. 1995. Molecular basis of somatic embryogenesis. In: Biotechnology in Agriculture and Forestry, Somatic Embryogenesis and Synthetic Seed, Vol. 30. In: Bajaj, Y. P. S. ed. SpringerVerlag, Berlin, Heidelberg, New York, pp.

Lin, C.S.; Chen, C.T.;Lin, C.C. and W.C., Chang . 2003. A method for inflorescence proliferation. Plant Cell Rep $21: 838-843$.

Lin, C.S.; Vidmar, J. and W.C. Chang. 2004. Effects of growth regulators on inflorescence proliferation of Bambusa edulis. Plant Growth Regul .43:221-225.

Lin, C.S.; Tseng, M.C. ; Hong, P.L. and W.C., Chang. 2006. Albino Inflorescence Proliferation of Dendrocalamus Latiflorus. In Vitro Cell. Dev. Biol.-Plant 42:331-335.

Mendoza M.G. and H.F. Kaeppler. 2002. In Vitro Cell. Dev.Biol. Plant, 38, 39-45.

Moura, E .f; Motoike, S. y; Ventrella, M .C; de sa junior, A. Q. and M. Carvalho. 2009. Somatic em- bryogenesis in macaw palm (Acrocomia aculeata) from zygotic embryos. Scientia Horticulturae, 119: 447-454.

Murashige T. and F. Skoog. 1962. A revised medium for rapid growth and bioassays with tobacco tissue culture. Physiol Plant 15:473-479.

Neuman, M. C.; Preece, J. E. and G., Gaffney. 1988. Production of somatic embryoid-like structures from immature cotyledonary tissue of black walnut (Juglans nigra L.). Hort Scieuce 23:807.

Othmani, a; Bayoudh, c; Drira, n; marrakchi, $\mathrm{M}$ and M., Trifi. 2009. Somatic embryogenesis and plant regeneration in date palm Phoenix dactylifera L., cv. Boufeggous is significantly improved by fine chopping and partial desiccation of embryonic callus. Plant Cell Tissue Organ Culture, 97: 71-79.

Pottino, B. G. 1981. Methods in plant tissue culture. Dept. of Hort., Agric. College, Maryland Univ., College Park, Maryland, USA, pp. 8-29.

Preeti, K. ;Kothari, S.1. 2004. In vitro culture of kodo millet:influence of 2,4-D and picloram in combination with kinetin on tissue initiation and regeneration. Plant Cell,Tissue and Organ Culture 77: 73-79.

Sidky, R.A.; Eldawyati, M. M. 2012. Proliferation of Female Inflorescences explants of Date Palm. Annals of Agricultural Sciences. 57: 2, 161-165.
Sidky
R.A.;
Gadalla
E.G.2013.Somatic embryogene- sis in Phoenix dactylifera: matu- ration, germination and reduc- 
tion of hyperhydricity during embryogenic cell suspension culture. Arab journal of biotechnology, 16:119-130.

Snedecor, G. W. and W. G. Cochran. 1980. "Statistical Methods", $7^{\text {th }}$ edition, the Lowa State Univ. press. Amer., PP: 365-372.

Tisserat, B.1979. Propagation of date palm (phoenix dactylifera L.) in vitro. J Exp Bot 30:1275-1283. doi: $10.1093 / \mathrm{j} \times \mathrm{b} / 30.6 .1275$.

Thomas, J. C. and F. R., Katterman.1986. Cytokinin activity induced by thidiazuron. Plant Physiol. 81:681-683.

Verdeil, J. 1; Buffard-Morel, J. and C., Pannetier. 1989. Somatic embryogenesis of coconut ( $\mathrm{Co}$ cos nucifera $\mathrm{L}$.) from leaf and inflorescence tissue research findings and prospects. Oleagineux, 44: 409-411.

Verdeil, J. 1; huet, C.; Grosdemange, F. and J., Buffard-Morel.1994. Plant regeneration from cultured immature inflorescences of coconut (Cocosnucifera L.): evidence for somatic embryogenesis. Plant Cell Reports, 13: 218221.

Verron, P.; Nard, M. and J., Cohat. 1995. In vitro organogenic competence of different organs and tissues of lily of the valley 'Grandiflora of Nantes'. Plant Cell Tissue Organ Cult 40:237242.

Zaid, A. and V., Hegarty. 2006. Focus on: Producing date palm trees with improved fruit yield, short height, and resistance to Bayoud disease. "The Third International Conference on Date Palm", 20-22 Feb 2006. Emirates Palace Hotel, Abu Dhabi, UAE.

Zimmerman, J.L. 1993. Somatic Embryogenesis: A Model for Early Development in Higher Plants. Plant Cell, 1993 October, 5(10): 1411-1423. 
تاثير تركيزات من البيكلورم وثيديازورن على تخليق الاجنه الجسميه من النورات الزهريه لنخيل البلح

\author{
رحاب أحمد صدقى \\ المعمل المركزى لأبحاث وتظوير نخيل البلح - مركز البحوث الزر اعية -الجيزة- مصر
}

(الملخص:

اجرى هذا البحث لدر اسه تاثير منظمات النمو على تخليق النور ات الزهريه غير الناضجه لنخيل البلح • تم زر اعه النور ات الزهريه فى مرحله البدايه على بيئه مور اثيجى وسكوج مزوده

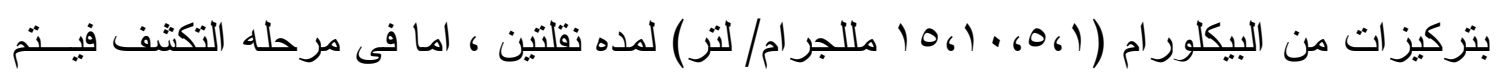
زر اعتها على بيئه محتويه تركيز ات من الثيديازورن مع نزكيز واحد من النفتالين اسيتك اســـ. لوحظ ان افضل تزكيز اعطى نمو للبر اعم كان ه او • ا مللجر ام/ لتز بيكلور ام • و عند در ســـ التاثير المتبقى لماده البيكلورم على تكثف البر اعم الزهريه فى وجــود ثــلاث تركيـز ات مــن الثيديازورن و النفتالين اسيتلك اسيد. وجد ان 0, · مللجر ام/ لتر الثيديازورن مـع ا , · مللجـر ام/ لتر نفتالين اسيتلك اسيد اكثر فاعليه لاحداث اجنه جسميه مباشره وكذلك تعطـى افـضل نـسبه تكثنف للاجنه المباثره ، بينما تؤدى التزكيز ات العاليه من البيكلورم الى تكـــوين كــالس. بـــتم تكوين النمو ات الخضريه على بيئه محتويه على ا, • مللجر ام/ لتز نفتالين اســبنك اسـبد ، ب, · ملاجر اج/ لتز كينتين وكذلك r, · ملاجر ام/ لتز بنزيل ادنين • وقد تحولت الاجنه الجسميه بصورة طبيعية إلى نبيتات جيدة النمو يمكن أقلمتها بنجاح. 